\title{
PENGARUH EDUKASI PELANGGAN PADA LOYALITAS PELANGGAN MELALUI KUALITAS JASA
}

\author{
Rully Arlan Tjahyadi \\ Universitas Kristen Maranatha \\ rullyarlan050679@gmail.com \\ Chandra Kuswoyo \\ Universitas Kristen Maranatha \\ chandrakuswoyo@yahoo.com \\ $\mathrm{Cen} \mathrm{Lu}$ \\ Universitas Kristen Maranatha \\ london3lay@yahoo.com \\ William Irianto \\ Universitas Kristen Maranatha \\ williamirianto@yahoo.com
}

\begin{abstract}
When customers actively participate in value creation, companies develop capabilities to understand customer need. It shows that companies and customers play an active role in creating value. Some experts suggest that the inculcation of value is essential in the co-creation process between companies and customers and that customer change from passive listeners to active players. So the value creation process must focus on developing processes to support customer learning. Customers must learn relevant skills and behaviours in the purchase, production, and use of goods or services to participate and contribute to creating value effectively. Educating customers and ensuring customer knowledge of a service is the primary determinant of service quality and customer loyalty. This study uses Path Analysis to examine customer education's effect on customer loyalty through service quality. The result shows that customer education affects customer loyalty directly or indirectly through service quality. This study's findings indicate that customer education is an essential concept in achieving competitive advantage. Customer education is understood as active customer participation to improve excellent service.
\end{abstract}

Keywords: customer education; customer loyalty; functional service quality; service quality technical; service quality

\section{PENDAHULUAN}

Perusahaan jasa secara berkelanjutan berupaya untuk mempertahankan hubungan jangka panjang dengan pelanggan dan untuk memahami faktor-faktor yang dapat membangun dan mempertahankan loyalitas pelanggan (Solem, 2016). Memahami kebutuhan dan melayani pelanggan menjadi konsep penting dalam perusahaan jasa. Pemahaman dalam melayani pelanggan melalui riset pasar, keterlibatan pelanggan dalam teknologi dan desain, serta pelayanan purna jual menjadi sangat penting dalam meningkatkan pelayanan terhadap pelanggan (Heskett, et al. 1990). Fokus bukan hanya melayani kebutuhan pelanggan, tetapi juga memahami lebih dulu apa yang menjadi kebutuhan mereka di masa akan datang (Noel, Ulrich, \& Mercer, 1990). Konsep customer anticipation menekankan pada upaya pemenuhan kebutuhan pelanggan di masa akan datang. Perubahan tuntunan pelanggan perlu direspon dengan pengenalan terhadap tren pelanggan sebagai kunci kesuksesan layanan. Edukasi pelanggan merupakan satu cara dalam upaya meningkatkan customer anticipation (Noel, Ulrich, \& Mercer, 1990).

Edukasi pelanggan diartikan sebagai partisipasi aktif pelanggan dalam melakukan pengembangan sumberdaya insani (Noel, Ulrich, \& Mercer, 1990). Proses penciptaan nilai merupakan salah satu cara upaya dalam pengembangan sumberdaya insani melalui keterlibatan pelanggan. Ketika pelanggan terlibat aktif dalam penciptaan nilai, maka perusahaan dapat mengembangkan kapabilitasnya untuk 
memahami kebutuhan pelanggan (Noel, Ulrich, \& Mercer, 1990). Ini menunjukkan bahwa perusahaan dan pelanggan secara bersama-sama berperan aktif dalam upaya untuk menciptakan nilai.

Para pakar mengusulkan bahwa nilai harus ditanamkan dalam proses co-creation antara perusahaan dan pelanggan. Proses co-creation merupakan upaya menciptakan nilai secara bersama-sama melalui berbagi pengetahuan antara perusahaan dengan pelanggan untuk menciptakan produk atau pelayanan yang lebih baik (Farhadyar \& Hosseini, 2018). Proses co-creation merubah peran pelanggan dari penerima pasif menjadi pemain aktif dalam upaya menciptakan nilai (Vargo, \& Lusch, 2008). Konsep Customer Knowledge Management (CKM) dipahami sebagai proses strategik yang mana perusahaan menempatkan pelanggan sebagai partner aktif dalam menciptakan nilai (Farhadyar \& Hosseini, 2018). Memeroleh pengetahuan dari sumber eksternal (pelanggan) jauh lebih menantang daripada sumber internal (karyawan). Upaya untuk meningkatkan hubungan jangka panjang dengan pelanggan menyoroti pentingnya konsep CKM (Khosravi \& Hussin, 2016). Mengembangkan CKM dalam organisasi membawa pada peningkatan kualitas produk dan layanan. Sehingga proses dalam penciptaan nilai harus fokus pada pengembangan proses untuk mendukung pembelajaran pelanggan (customer learning) dan implementasi CKM dalam organisasi. Pelanggan harus mempelajari keahlian dan perilaku yang relevan dalam pembelian, produksi, dan penggunaan barang atau jasa agar dapat berpartisipasi dan berkontribusi aktif (Payne, et al., 2009).

Efektivitas penjualan akan menjadi isu penting ketika suatu layanan kompleks, pelanggan kurang berpengalaman, dan pelanggan menghadapi ketidakpastian (Suh, et al., 2015). Upaya untuk mengurangi kesulitan yang dihadapi pelanggan, strategi edukasi pelanggan telah diaplikasikan dalam berbagai konteks jasa. Edukasi pelanggan dalam konteks jasa keuangan telah digunakan untuk membedakan perusahaan dari pesaing, menambah nilai, meningkatkan loyalitas, dan membantu meretensi pelanggan (Bell \& Eisingerich, 2007; Burton, 2002). Dalam industri retail, edukasi pelanggan telah diaplikasikan untuk mengantisipasi ketidaknyaman pelanggan (Balabanis, Reynolds, Simintiras, 2006). Sehingga, mengedukasi pelanggan dan memastikan level pengetahuan pelanggan terhadap suatu layanan menjadi determinan utama kualitas jasa dan loyalitas pelanggan (Antonios, 2011; Suh, Greene, Israivol, \& Rho, 2015). Farhadyar dan Hosseini (2018) memaparkan bahwa edukasi pelanggan sebagai satu cara terbaik dalam Customer Knowledge Management (CKM) yang memainkan peran penting dalam meningkatkan kepuasan pelanggan. Strategi edukasi pelanggan bertujuan untuk memeroleh pengetahuan berbagai kebutuhan dan pengalaman pelanggan dalam pembelian, penggunaan, dan mempertahankan produk. Informasi tersebut penting dalam memprediksi tren perkembangan pasar, identifikasi peluang pasar baru, meningkatkan produk, dan menentukan tujuan organisasi. Investigasi edukasi pelanggan dalam konteks Pendidikan Tinggi belum banyak dilakukan. Dalam konteks Pendidikan Tinggi (PT), kualitas layanan menjadi konsep sangat penting bagi kesuksesan PT. Sehingga penting bagi perguruan tinggi untuk memfokuskan pada kualitas layanan sebagai topik sentral dalam wacana strategi bersaing. Edukasi pelanggan menjadi cara bagi PT untuk terus meningkatkan kualitas layanan dengan menempatkan mahasiswa sebagai sumber pengetahuan dan memainkan peran aktif dalam proses value co-creation (Kuswoyo \& Tjahyadi, 2017).

Peningkatan kualitas jasa secara berkelanjutan melalui strategi edukasi pelanggan menunjukkan upaya penyedia layanan untuk terus menyampaikan layanan prima bagi pelanggan. Kualitas jasa memiliki peran strategik untuk meraih keunggulan kompetitif (Petruzzellis, D’Uggento, \& Romanazzi, 2006). Kualitas jasa merupakan topik sentral investigasi dalam literature pemasaran jasa. Kang (2006) menjelaskan bahwa dalam beberapa dekade terkahir, pemahaman dan identifikasi kualitas jasa telah dilakukan. Penekanan pada isu-isu pengukuran dan fokus pada model kualitas jasa (Model SERVQUAL) telah dilakukan (Parasuraman, Zeithaml, \& Berry, 1988). Model SERVQUAL tersebut hanya memfokuskan pada bagaimana suatu layanan diberikan (service-delivery process) atau fokus pada aspek fungsional (functional quality). Selain pada proses, hasil yang secara aktual pelanggan terima dari layanan perlu dipertimbangkan dalam mengukur kualitas jasa (technical quality). Aspek fungsional (functional aspect) fokus pada penilaian pelanggan tentang bagaimana jasa itu berlangsung atau cara-cara suatu layanan diberikan pada pelanggan. Aspek teknis (technical aspect) diartikan 
sebagai penilaian pelanggan terhadap hasil dari proses jasa. Kualitas teknis menjelaskan tentang layanan yang secara aktual diterima oleh pelanggan (Kang, 2006).

Suh et al. (2015) meyakini bahwa edukasi pelanggan juga mengarah pada loyalitas pelanggan dan hubungan yang lebih menguntungkan. Studi tentang loyalitas pelanggan terus menjadi isu utama terkait dengan pengukuran loyalitas pelanggan, yaitu pengukuran berdasarkan pada dimensi perilaku (behavioral) dan dimensi sikap (attitudinal). Tujuan dari penelitian ini adalah untuk menginvestigasi peran edukasi pelanggan dalam meningkatkan loyalitas, serta peran kualitas jasa sebagai mediasi hubungan antara edukasi pelanggan dan loyalitas pelanggan.

\section{KAJIAN PUSTAKA DAN PENGEMBANGAN HIPOTESIS}

\section{Edukasi Pelanggan}

Bonfanti \& Brunetti (2015) mendefinisikan edukasi pelanggan sebagai aktivitas pembelajaran yang berkelanjutan dan terorganisir yang didesain untuk memberikan sikap, pengetahuan, dan keahlian bagi pelanggan. Edukasi pelanggan dapat ditunjukkan melalui self instructional suatu produk. Suh et al. (2015) menyatakan bahwa edukasi pelanggan dapat menjadikan keunggulan kompetitif suatu organisasi melalui keterlibatan aktif pelanggan dalam proses penciptaan nilai. Terdapat beberapa implikasi edukasi pelanggan diantaranya yaitu (1) Peran dan tanggungjawab departemen Sumberdaya Insani berubah ketika pelanggan dilibatkan dalam edukasi. Program pelatihan yang dikembangkan tidak hanya bagi karyawan saja, melainkan juga dapat dikembangkan bagi pelanggan. (2) Praktik sumberdaya insani harus menjadi keunggulan kompetitif bagi perusahaan. Untuk mencapainya, Departemen Sumberdaya Insani harus belajar mengetahui cara menciptakan nilai bagi perusahaan. Menambah nilai bagi perusahaan (melalui membangun kepercayaan antara perusahaan dan pelanggan, meningkatkan pemahaman proses, membangun komitmen bersama antara perusahaan dan pelanggan, serta membantu menciptakan proses manajemen bari baik bagi perusahaan maupun pelanggan) akan terealisasi ketika para profesional Departemen Sumberdaya Insani memfokuskan perhatiannya pada mengedukasi pelanggan. (3) Mengedukasi pelanggan memaksa penilaian kembali terhadap edukasi manajemen tradisional, pengembangan tim, dan penciptaan nilai (Noel, Ulrich, \& Mercer, 1990).

\section{Kualitas Jasa}

Penilaian konsumen terhadap kualitas suatu jasa didasarkan pada pengalaman mereka setelah membeli dan mengkonsumsi jasa tersebut. Jasa yang berkualitas adalah jasa yang dapat menciptakan kepuasan konsumen. Kualitas jasa dihasilkan dari perbandingan performa yang dirasakan dan yang diharapkan. Kualitas jasa diakui memiliki banyak dimensi (Grönroos, 1984). Dimensi kualitas jasa dari Perspektif Eropa telah berkontribusi terhadap studi tentang kualitas jasa (Kuswoyo \& Tjahyadi, 2017). Lehtinen \& Lehtinen (1991) mengkategorikan 3 dimensi kualitas jasa - physical quality (aspek fisik dari jasa), interactive quality (aspek interaksi pelanggan dan penyedia jasa), dan corporate image (citra penyedia jasa).

Studi lainnya telah mengembangkan dua dimensi kualitas jasa - kualitas fungsional dan kualitas teknis (Grönroos, 1984; Kang, 2006). Kualitas jasa teknis berkenaan dengan apa yang secara real pelanggan terima selama service encounter. Artinya bahwa kualitas teknis merujuk pada kualitas luaran (service output). Kualitas jasa fungsional menekankan pada bagaimana jasa diberikan. Kualitas jasa fungsional juga sejauhmana penyedia jasa memberikan jasa yang sopan dan penuh perhatian serta empati terhadap situasi yang dihadapi pelanggan (Suh, et al., 2015). Lehtinen \& Lehtinen (1991) mendefisikan kualitas jasa berdasarkan pada proses (dinilai pelanggan selama proses berlangsung) dan luaran (dinilai pelanggan setelah jasa itu berikan). Swartz dan Brown (1989) menyatakan terdapat dua kategori dimensi kualitas yaitu "apa" (penilaian setelah jasa itu disampaikan) dan "bagaimana" (evaluasi selama jasa itu disampaikan).

\section{Loyalitas Pelanggan}

Loyalitas pelanggan dapat didefinisikan sebagai intensi pelanggan untuk tetap bersama organisasi, komitmen mereka untuk meningkatkan kedalaman dan keluasan hubungan dengan organisasi, dan intensi pelanggan untuk membantu kesuksesan organisasi melalui komunikasi word-of-mouth (Suh, et 
al., 2015). Day (1962) mendefinisikan loyalitas sebagai pembelian berulang dengan adanya disposisi internal yang kuat. Disposisi internal dipahami sebagai dorongan sikap yang kuat yang memengaruhi perilaku. Artinya bahwa perilaku pembelian ulang sangat ditentukan oleh adanya sikap (attitude) yang kuat. Loyalitas juga dipahami sebagai preferensi pelanggan atau intensi beli ulang (repurchase intention). Preferensi pelanggan atau intensi beli ulang terhadap merek yang sama memerlukan konsistensi ketiga struktur psikologis - kognitif (berkaitan dengan keyakinan pelanggan terhadap suatu objek merek), afektif (perasaan emosional pelanggan terhadap merek), dan konatif (disposisi perilaku pelanggan terhadap suatu merek) (Tjahyadi, 2009).

\section{Pengembangan Hipotesis}

Edukasi pelanggan merupakan aktivitas pembelajaran yang berkelanjutan dan terorganisir yang dirancang untuk memberikan sikap, pengetahuan, dan keahlian bagi pelanggan Bonfanti dan Brunetti (2015). Perusahaan harus mempertimbangkan edukasi sebagai strategi kompetitif utama. Sebagai strategi bersaing utama bagi perusahaan, edukasi dapat memberikan manfaat bagi perusahaan berupa profit yang lebih besar. Perusahaan dapat mempertahankan pelanggan yang puas dan berkontribusi terhadap sikap pelanggan yang menyenangkan terhadap produk, serta dapat mengurangi konfrontasi (McNeal, 1978).

Beberapa studi menemukan bahwa edukasi pelanggan telah digunakan untuk membedakan perusahaan dari pesaing, menambah nilai bagi perusahaan, meningkatkan loyalitas, dan membantu dalam meretensi pelanggan (Burton, 2002). Lainnya menunjukkan bahwa edukasi pelanggan dapat meningkatkan kualitas jasa (Suh et al., 2015) dan telah diaplikasikan untuk mengantisipasi ketidaknyaman pelanggan (Balabanis, Reynolds, dan Simintiras, 2006). Sehingga, mengedukasi pelanggan dan memastikan level pengetahuan pelanggan terhadap suatu layanan menjadi penentu utama kualitas jasa dan loyalitas pelanggan (Antonios, 2011; Suh et al., 2015).

Peneltian ini juga akan memfokuskan pada peran kualitas jasa dalam memengaruhi loyalitas pelanggan. Beberapa penelitian lainnya menunjukan hasil yang konsisten yang mana kualitas jasa memainkan peran penting dalam meningkatkan kesetiaan (Behera, 2018; Ivanauskiené \& Volungénaité, 2014; Suh et al., 2015)

Studi ini juga akan memfokuskan pada peran edukasi pelanggan dalam memengaruhi loyalitas pelanggan. Edukasi pelanggan dapat dipahami sebagai tingkat yangmana penyedia layanan memberikan pelanggan dengan keahlian dan kemampuan untuk memanfaatkan informasi (Burton, 2002). Memberikan pelanggan keahlian dan kemampuan untuk memanfaatkan informasi dapat meningkatkan loyalitas pelanggan (Bell \& Eisingerich, 2007). Studi Sharma dan Patterson (1999) menemukan bahwa mengedukasi pelanggan dapat meningkatkan kepercayaan terhadap organisasi dan komitmen terhadap hubungan. Upaya edukasi pelanggan juga dapat meningkatkan efisiensi bagi pelanggan yang dihubungkan dengan semakin tingginya tingkat pembelian ulang pelanggan (Xue \& Harker, 2002). Investasi terhadap strategi edukasi pelanggan akan memperkuat persepsi pelanggan terhadap positioning perusahaan sebagai penyedia layanan berkualitas tinggi (Burton, 2002) sehingga besar kemungkinan pelanggan untuk tetap dengan organisasi (Bell \& Eisingerich, 2007).

H1: Edukasi pelanggan berpengaruh positif terhadap loyalitas pelanggan.

$\mathrm{H} 2$ : Edukasi pelanggan berpengaruh positif terhadap loyalitas pelanggan dengan dimediasi kualitas jasa.

\section{METODE PENELITIAN}

Teknik survei melalui penyebaran kuesioner kepada para partisipan digunakan sebagai cara untuk mengumpulkan data penelitian. Partisipan dalam survei ini adalah mahasiswa dari Fakultas Ekonomi Universitas Kristen Maranatha (FE UKM). Survei dilakukan pada bulan September-Oktober 2019. 
Tjahyadi dkk. Pengaruh Edukasi Pelanggan pada Loyalitas Pelanggan melalui Kualitas Jasa

Total 350 kuesioner didistribusikan dan sebanyak 300 responden yang dapat dilakukan analisis lebih lanjut. Sebanyak 50 kuesioner dieliminasi karena data yang tidak lengkap.

Data dikumpulkan melalui penyebaran kuesioner kepada mahasiswa FE UKM. Setiap item pernyataan dalam bahasa Inggris diterjemahkan ke dalam bahasa Indonesia. Edukasi pelanggan terdiri atas empat item pernyataan. Item-item tersebut dipilih karena menangkap tingkat yang mana penyedia layanan menyediakan informasi yang perlanggan butuhkan. Kualitas jasa didasarkan pada aspek fungsional dan teknis, yang terdiri atas delapan butir pernyataan/pertanyaan. Loyalitas pelanggan mengadopsi pendekatan attitudinal yang digambarkan melalui preferensi atau niat beli ulang dan rekomendasi pelanggan ke pelanggan lain. Loyalitas pelanggan terdiri atas tiga item pernyataan/pertanyaan. Seluruh item pernyataan dalam kuesioner ini diadaptasi dari Suh et al. (2015). Seluruh item pernyataan diukur dengan menggunakan 5 (lima) Likert scales.

Uji validitas dan reliabilitas dilakukan terhadap seluruh item-item yang digunakan dalam mengembangkan suatu konstruk teoritis. Analisis faktor dari seluruh variabel yang diukur dan analisis reliabilitas dengan menggunakan nilai cronbach alpha dilakukan.

Pengujian setiap hipotesis yang diusulkan dalam penelitian ini menggunakan metode Path Analysis. Metode Path Analysis merupakan pengembangan dari multiple regression. Metode Path Analysis digunakan dalam pengujian hipotesis dalam penelitian ini adalah untuk menaksir hubungan kausalitas antar-variabel yang telah ditetapkan sebelumnya berdasarkan teori (Ghozali, 2013). Uji hipotesis dilakukan dengan melihat tingkat signifikansi pengaruh variabel independen terhadap variabel dependen $(\alpha<0.05)$.

\section{HASIL DAN PEMBAHASAN}

\section{Hasil Uji Instrumen Penelitian}

Kuesioner dinyatakan valid jika setiap item pernyataan pada kuesioner mampu mengungkapkan sesuatu yang akan diukur oleh kuesioner tersebut (Ghozali, 2013). Hasil uji validitas menjelaskan bahwa nilai KMO $=0.931$ serta nilai Bartlett test dan Chi-square $=3601.057$ dan signifikan pada 0.000 menunjukan uji analisis faktor dapat dilanjutkan. Hasil rotation menjelaskan bahwa item CE1-CE4 berkelompok pada faktor 1, SQ4-SQ6 mengelompok pada faktor 2, dan item SL1-SL3 mengelompok pada faktor 3 .

Reliabilitas merupakan alat untuk mengukur konsistensi butir pernyataan dalam kuesioner dengan menggunakan analisis cronbach alpha. Setiap item harus memenuhi nilai cronbach's Alpha >0.6. Berdasarkan Tabel 5, seluruh variabel penilitian dinyatakan reliabel karena memiliki cronbach's alpha 0.956 untuk konstruk edukasi pelanggan, 0.931 untuk konstruk kualitas jasa dan 0.917 untuk konstruk loyalitas pelanggan.

\section{Hasil Uji Asumsi Klasik}

Model regresi yang baik seharusnya tidak terjadi korelasi antar variabel dependen (Ghozali, 2013). Konstruk penelitian dinyatakan terbebas multikolinearitas jika nilai Tolerance $>0.1$ dan nilai Variance Inflation Factor (VIF) <10. Hasil uji multikolinearitas menunjukkan seluruh konstruk item penelitian memiliki nilai VIF 2.791 dan angka tolerance $0.358(\geq 0.1)$. Hasil uji heterokedastisitas menunjukkan bahwa data penelitian ini terbebas dari uji heteroskedastisitas karena memiliki nilai Sig $>5 \%$ (CE $=0.473$ dan $\mathrm{SQ}=0.308$ ). Hasil uji normalitas menujukkan bahwa data berdistribusi normal.

\section{Hasil Pengujian Analisis Jalur}

Hasil olahan IBM SPSS 23 pada Tabel 1 menjelaskan nilai unstandardized beta CE (edukasi pelanggan) pada persamaan 1 sebesar 0.757 (signifikan pada 0.000) yang berarti bahwa edukasi pelanggan memengaruhi kualitas jasa. Persamaan regresi 2 nilai unstandardized beta untuk CE 0.379 dan SQ 0.478 serta siginifikan pada 0.000 (Tabel 2). Hasil analisis jalur menunjukkan bahwa edukasi pelanggan berpengaruh langsung terhadap loyalitas pelanggan (H1 didukung) dan berpengaruh tidak langsung yaitu melalui kualitas jasa $(\mathrm{H} 2)$. Besarnya pengaruh langsung adalah 0.413 , sedangkan 
besarnya pengaruh tidak langsung adalah $(0.801) \times(0.493)=0.395$, atau total pengaruh edukasi pelanggan terhadap loyalitas pelanggan $=0.413+(0.801 \times 0.493)=0.808$.

Tabel 1.

COEFFICIENTS ${ }^{a}$ PERSAMAAN REGRESI 1

\begin{tabular}{|c|c|c|c|c|c|c|}
\hline & & Unstand & Coefficients & $\begin{array}{c}\text { Standardized } \\
\text { Coefficients }\end{array}$ & & \\
\hline Model & & $B$ & Std. Error & Beta & $t$ & Sig. \\
\hline \multirow[t]{2}{*}{1} & (Constant) & .677 & .127 & & 5.324 & .000 \\
\hline & $T C E$ & .757 & .033 & .801 & 23.101 & .000 \\
\hline
\end{tabular}

Sumber: Output IBM SPSS 23

Tabel 2.

COEFFICIENTS ${ }^{a}$ PERSAMAAN REGRESI 2

\begin{tabular}{|c|c|c|c|c|c|c|}
\hline \multirow[b]{2}{*}{ Model } & & \multicolumn{2}{|c|}{ Unstandardized Coefficients } & $\begin{array}{c}\text { Standardized } \\
\text { Coefficients }\end{array}$ & \multirow[b]{2}{*}{$T$} & \multirow[b]{2}{*}{ Sig. } \\
\hline & & $B$ & Std. Error & Beta & & \\
\hline \multirow[t]{3}{*}{1} & (Constant) & .501 & .110 & & 4.561 & .000 \\
\hline & TCE & .379 & .045 & .413 & 8.367 & .000 \\
\hline & TSQ & .478 & .048 & .493 & 9.997 & .000 \\
\hline a. Varic & 1 Dependen & & & & & \\
\hline
\end{tabular}

Sumber: Output IBM SPSS 23

\section{Pembahasan}

Hal penting bagi organsisasi jasa khususnya intitusi pendidikan adalah kapabilitas dalam memahami kebutuhan dan keinginan pelanggan, serta kemampuan dalam memberikan layanan prima bagi mereka. Penting bagi institusi pendidikan tinggi untuk dapat memrediksi kebutuhan pelanggan di masa akan datang. Perubahan tuntunan pelanggan perlu direspon dengan pengenalan terhadap tren pelanggan sebagai kunci kesuksesan layanan. Salah satu cara dalam meningkatkan customer anticipation adalah edukasi pelanggan. Edukasi pelanggan diartikan sebagai partisipasi aktif pelanggan dalam proses penciptaan nilai. Ketika pelanggan terlibat aktif dalam penciptaan nilai, maka perusahaan mengembangkan kapabilitasnya untuk memahami kebutuhan pelanggan (Noel, Ulrich, \& Mercer, 1990). Sehingga mengedukasi pelanggan dan memastikan level pengetahuan pelanggan terhadap suatu layanan menjadi determinan utama kualitas jasa dan loyalitas (Antonios, 2011; Suh et al., 2015).

Studi ini menemukan bahwa edukasi pelanggan memengaruhi loyalitas (H1 diterima). Hasil tersebut mengkonfirmasi beberapa penelitian sebelumnya. Burton (2002) menjelaskan bahwa edukasi pelanggan digunakan sebagai alat diferensiasi perusahaan dari pesaing, memberikan nilai tambah bagi perusahaan, dan membantu dalam meretensi pelanggan. Hasil studi Suh et al. (2015) menunjukkan bahwa edukasi pelanggan dapat meningkatkan kualitas jasa. Memberikan edukasi terhadap pelanggan menjadi penentu utama kualitas jasa dan loyalitas pelanggan (Antonios, 2011; Suh et al., 2015). Hasil penelitian ini juga menemukan peran kualitas jasa dalam memengaruhi loyalitas. Hasil penelitian ini mengkonfirmasi studi sebelumnya yang menemukan bahwa kualitas jasa memengaruhi loyalitas pelanggan (Behera, 2018; Ivanauskiené \& Volungénaité, 2014; Suh et al., 2015). Hasil lainnya menunjukkan bahwa peran edukasi pelanggan dalam meningkatkan loyalitas pelanggan. Hasil studi sebelumnya menujukkan bahwa bahwa memberikan edukasi pelanggan akan meningkatkan kepercayaan dan komitmen terhadap hubungan (Sharma \& Patterson, 1999), serta dapat meningkatkan pembelian ulang pelanggan (repurchase) (Xue \& Harker, 2002). Penelitian ini juga menguji peran kualitas layanan sebagai variabel mediasi hubungan antara edukasi pelanggan dan loyalitas pelanggan. Berdasarkan pengujian dengan Path Analysis, hasilnya menunjukkan bahwa 
kualitas layanan memainkan peran sebagai partial mediation. Artinya bahwa baik edukasi pelanggan maupun kualitas layanan memiliki pengaruh langsung secara signifikan terhadap loyalitas pelanggan.

Penelitian ini mendukung teori bahwa edukasi pelanggan dapat memberikan keunggulan kompetitif organisasi. Partisipasi pelanggan menjadi sangat penting dalam meningkatkan pelayanan terhadap pelanggan. Konsep customer anticipation menekankan pada upaya memahami dan memenuhi kebutuhan pelanggan di masa akan datang. Kunci kesuksesan layanan adalah dengan merespon perubahan tuntunan pelanggan dan memahami tren pelanggan. Edukasi pelanggan merupakan satu cara dalam upaya meningkatkan customer anticipation. Kegiatan focus group discussion (FGD) dengan pelanggan sebagai salah satu teknik yang dapat digunakan untuk menggali informasi dari perspektif pelanggan ketika organisasi akan meningkatkan suatu layanan. Artinya bahwa pelanggan berperan aktif dalam upaya organisasi untuk melakukan perbaikan dan peningkatan layanan. Temuan pada studi ini juga dapat dijadikan sebagai masukan bagi Perguruan Tinggi untuk meningkatkan kualitas jasa dan retensi mahasiswa. Edukasi pelanggan menjadi fokus penting dalam upaya Perguruan Tinggi untuk menciptakan nilai bagi pelanggan. Partisipasi pelanggan dalam proses penciptaan nilai menunjukkan peran Perguruan Tinggi untuk melibatkan pelanggan dalam meningkatkan layanan.

Praktik sumber daya insani harus menjadi keunggulan kompetitif bagi perusahaan. Untuk mencapainya, Departemen Sumberdaya Insani harus belajar mengetahui cara menciptakan nilai. Proses penciptaan nilai juga harus dilihat dari perspektif pelanggan. Membangun kepercayaan antara perusahaan dan pelanggan, meningkatkan pemahaman proses, membangun komitmen bersama antara perusahaan dan pelanggan, membantu menciptakan proses manajemen baik, serta berbagi pengetahuan bersama pelanggan merupakan upaya untuk menciptakan nilai melalui edukasi pelanggan. Edukasi pelanggan dipahami sebagai partisipasi aktif pelanggan. Ketika pelanggan terlibat aktif dalam penciptaan nilai, maka perusahaan mengembangkan kapabilitasnya untuk memahami kebutuhan pelanggan (Noel, Ulrich, dan Mercer, 1990). Ini menunjukkan bahwa perusahaan dan pelanggan secara bersama-sama berperan aktif dalam upaya untuk menciptakan nilai.

\section{KESIMPULAN}

Hasil penelitian menunjukkan bahwa edukasi pelanggan memiliki pengaruh langsung dan tidak langsung pada loyalitas pelanggan. Kualitas jasa memainkan peran partial mediation hubungan antara edukasi pelanggan dan loyalitas. Hasil penelitian dapat memberikan implikasi bagi secara teoritis maupun praktis. Temuan pada penelitian ini menunjukan bahwa edukasi pelanggan merupakan konsep penting dalam mencapai keunggulan kompetitif organisasi. Edukasi pelanggan dapat diaplikasikan dalam berbagai industri jasa, termasuk Perguruan Tinggi. Hasil dari studi ini telah mengkonfirmasi penelitian-penelitian sebelumnya bahwa edukasi pelanggan memainkan peran penting dalam meningkatkan kualitas layanan dan kesetiaan pelanggan. Menempatkan pelanggan sebagai bagian dalam proses value creation menjadi hal sangat penting sebagai upaya Perguruan Tinggi untuk meningkatkan pelayanan dan retensi pelanggan.

Penelitian ini hanya difokuskan pada Fakultas Ekonomi Universitas Kristen Maranatha. Sehingga hasil dari penelitian ini tidak dapat digeneralisasikan dalam konteks jasa lain atau Perguruan Tinggi lain. Variabel peneltian yang digunakan dalam penelitian ini sebatas pada pengaruh edukasi pelanggan dalam meningkatkan loyalitas pelanggan melalui kualitas jasa. Penelitian akan datang diharapkan dapat diuji pada setting penelitian dalam konteks industri Perguruan Tinggi yang lebih luas dan konteks jasa yang berbeda. Pengujian edukasi pelanggan dalam konteks produk atau jasa dengan keterlibatan pelanggan yang rendah (low involvement) dapat dilakukan. Penting untuk dilakukan pengujian kepercayaan dan komitmen dalam konteks customer-brand relationship.

\section{DAFTAR PUSTAKA}

Antonios, J. (2011). Understanding The Effects of Customer Education on Customer Loyalty. Business Leadership Review, September, 1-15. 
Balabanis, G., Reynolds, N., \& Simintiras, A. (2006). Bases of E-Store Loyalty: Perceived Switching Barriers and Satisfaction. Journal of Business Research, 59(2), 214-224.

Behera, J. P. (2018). Impact of Service Quality on Customer Loyalty in Indian Banking Sector in Odisha. International Journal for Research in Engineering Application \& Management, 04(02), 320-327.

Bell, S. J. \& Eisingerich, B. (2007). The Paradox of Customer Education: Customer Expertise and Loyalty in the Financial Services Industry. European Journal of Marketing, 41(5/6), 466-486.

Bonfanti, A., \& Brunetti, F. (2015). Effects of customer education in terms of customer perceived value: The role of customer evaluation skills. Sinergie Italian Journal of Management, 33(97), 219-238.

Burton, D. (2002). Consumer Education and Service Quality: Conceptual Issues and Practical Implications. Journal of Services Marketing, 16(2), 125-142.

Day, G.S. (1969). A two-dimensional concept of brand loyalty. Journal of AdvertisingResearch, 9(3), 29-36.

Dick, A. \& Basu, K. (1994). Customer Loyalty: Toward an Integrated Conceptual Framework. Journal of the Academy of Marketing Science, 22(2), 99-113.

Farhadyar, A. \& Hosseini, H. K. (2018). Investigating the Effect of Customer Education on Customer Satisfaction of Nano Foods in Iran. Revista Publicando, 5(17), 338-356.

Ghozali, I. (2013). Aplikasi Analisis Multivariate dengan Program IBM SPSS 21: Update PLS Regresi. Badan Penerbit Universitas Diponegoro, Semarang.

Grönroos, C. (1984). A Service Quality Model and Its Marketing Implications. European Journal of Marketing, 18(4), 36-44.

Heskett, J. L., Sasser, W. E., Jr., \& Hart, C. W. (1990). Service breakthroughs. New York: Free Press.

Ivanauskiené, N. \& Volungénaité, J. (2014). Relations between Service Quality and Customer Loyalty: An Empirical Investigation of Retail Chain Stores in Emerging Markets. American International Journal of Social Science, 3(2), 113-120.

Kang, G. (2006). The Hierarchical Structure of Service Quality: Integration of Technical and Functional Quality. Managing Service Quality, 16(1), 37-50.

Khosravi, A. \& Hussin, A. (2016). Customer Knowledge Management: Development Stages and Challenges. Journal of Theoretical and Applied Information Technology, 91(2), 264-274.

Kuswoyo, C. \& Tjahyadi, R. A. (2017). Dimensi-Dimensi Kualitas Layanan: Pengujian Model Kualitas Layanan Dari Perspektif Europa. Jurnal Manajemen Maranatha, 17(1), 71-80.

Lehtinen, U., \& Lehtinen, J. R. (1991). Two Approaches to Service Quality Dimensions. The Service Industries Journal, 11(3), 287-303.

McNeal, J.U. (1978). Consumer education as a competitive strategy. Business Horizons, 21(1), 50-56.

Morgan, R. M. \& Hunt, S. D. (1994). The Commitment-Trust Theory of Relationship Marketing. Journal of Marketing, 58(July 1994), 20-38. 
Tjahyadi dkk. Pengaruh Edukasi Pelanggan pada Loyalitas Pelanggan melalui Kualitas Jasa

Noel, J. L., Ulrich, D., \& Mercer, S. R. (1990). Customer Education: A New Frontier for Human Resource Development. Human Resource Management, 29(4), 411-434.

Parasuraman, A., Zeithaml, V. A., \& Berry, L. L. (1988). SERVQUAL: A Multiple-Item Scale for Measuring Consumer Perceptions of Service Quality. Journal of Retailing, 64(1), 12-40.

Payne, A., Storbacka, K., Frow, P., \& Knox, S. (2009). Co-Creating Brands: Diagnosing and Designing the Relationship Experience. Journal of Business Research, 62(3), 379-389.

Petruzzellis, L., D’Uggento, A. M., \& Romanazzi, S. (2006). Student Satisfaction and Quality of Service in Italian Universities. Managing Service Quality, 16(4), 349-364.

Sharma, N. \& Patterson, P. G. (1999). The Impact of Communication Effectiveness and Service Quality on Relationship Commitment in Consumer, Professional Services. The Journal of Services Marketing, 13(2), 151-170.

Solem, B. A. A. (2016). Influences of Customer Participation and Customer Brand Engagement on Brand Loyalty. Journal of Consumer Marketing, 33(5), 332-342.

Suh, M., Greene, H., Israivol, B., \& Rho, T. (2015). The Impact of Customer Education on Customer Loyalty Through Service Quality. Services Marketing Quarterly, 36(3), 261-280.

Tjahyadi, R. A. (2009). Pengujian Komitmen Multidimensional Allen dan Meyer dalam Konteks Pemasaran Jasa. Integritas:Jurnal Manajemen Bisnis, 2(3), 195-219.

Vargo, S. L. \& Lusch, R. F. (2008). Service-Dominant Logic: Continuing the Evolution. Journal of the Academy of Marketing Science, 36(1), 1-10.

Xue, M. \& Harker, P. T. (2002). Customer Efficiency: Concept and Its Impact on E-Business Management. Journal of Service Research, 4(4), 253-267. 